\title{
Wind Power Accommodation by CHP Based on Electric Boiler and Heat Accumulator
}

\author{
Liguo Fan* \\ School of Business Administration, North China Electric Power University, Baoding 071003, P.R.China \\ ${ }^{*}$ Corresponding author
}

\begin{abstract}
The new method of accommodating wind power based on electric boilers and heat accumulators with combined heat and power(CHP) is presented in the paper. Firstly, the cause of tremendous wind power curtailment in the north power grid of China is introduced. Secondly, thermoelectric characteristics of CHP is introduced. Thirdly, implement mode of advancing wind power accommodation based on electric boiler and heat accumulator is presented. Finally, economic benefits of increasing wind power accommodation are calculated and the meaningful conclusion is obtained by example analysis.
\end{abstract}

Keywords-wind power accommodation; CHP; electric boilers; heat accumulators

\section{INTRODUCTION}

With rapid development of wind power industry, the problem of significant wind power curtailment becomes increasingly prominent. According to National Energy Board counted, curtailed wind powers of the country are about 339 hundred million $\mathrm{kWh}$, direct losses are 180 hundred million Yuan in 2015. Lack of the peak regulation ability of power system is one of the most important causes[1] of tremendous wind power curtailments. The north power grid of China is main divisions of wind power development. Its' power structures are coal-fired thermal power unit and load regulating capacity is insufficient. Confront by the technical difficulties of lack of accommodation capacity and external delivery capability of local power grid because of large-scale wind power locating the end of power grid in the areas. Combined heat and power units operating in the mode of forced power output determined by heat in order to meet the demand of heat load will further decrease the peak regulation ability of CHP and increase contradiction of lack of the peak regulation ability of the system. It causes lots of wind power curtailment.

In order to improve wind power accommodation the domestic and foreign scholars proposed lots of measures. Heat accumulator technology and energy alternative technology are in focus considerable[2-6]. Currently foreign researches of CHP units configuring by heat accumulator concentrated on how to formulate operation strategy for CHP units and small distributed back pressure gas turbines[7]. Domestic researches focused on configuring water source heat pump technology[8] or electric boiler or heat accumulator for CHP units [9].

The project of decoupling the constraint of forced power output determined by heat by configuring large electric boilers and heat accumulators for CHP is proposed in the paper. A actual case of a thermal power unit is applied in the paper.

\section{THERMOELECTRIC CHARACTERISTICS OF CHP UNITS}

Heating mode of CHP units and regional boilers operating collectively is adopted in winter heating period. Because of inefficiency and high pollution of regional boiler, heating mode of CHP becomes popular. CHP units include backpressure units and extraction condensation units. Coupling relation between electric power output and heating power output is called thermoelectric characteristics.

For backpressure units, backpressure exhaust of turbines transfer heat with heat supply network by heat exchanger and achieve supply heat for heat loads by heat supply network. Its' heating power and electric power present approximately coupling relation. Electric power of CHP units are decided by heating power and heat-to-electric ratio is confirmed. Backpressure units have not regulating capacity in order to meet heat load demands in heating period.

For extraction condensation units, a part of steams as heat source are extracted from intermediate pressure cylinder and low pressure cylinder of turbines for supplying heat. Heat-to-electric ratio of turbines are adjusted by accommodating steam extraction under the conditions of satisfying operation, therefore the relation of heating power and electric power can be commonly presented operating region. Electric power can be adjusted within limits for some heating power. When heat loads become higher, steam extraction increasing results in reducing adjustable range of electric power. If wind power become large, extraction condensation units need operate in minimum condensing condition in order to enough spaces for wind power. At present electric power of CHP units are decided by heating power and CHP units have not regulating capacity.

\section{IMPlEMENTATION MOdE OF AdVANCING Wind POWER ACCOMMODATION BASED ON ELECTRIC BOILERS AND HEAT ACCUMULATORS}

Power system and thermodynamic system are connected by CHP units in mains side. Since CHP units have thermoelectric characteristics constraint of forced power output determined by heat, it limits electric power. If CHP units can accommodate tremendous wind power curtailment by reducing forced power output result from forced power output determined by heat, insufficient heat supply of CHP units need be compensated. The project is composed that compensating supply heat and decoupling the constraint of forced power output determined by heat by configuring large electric boiler and heat accumulator for CHP in the paper. 


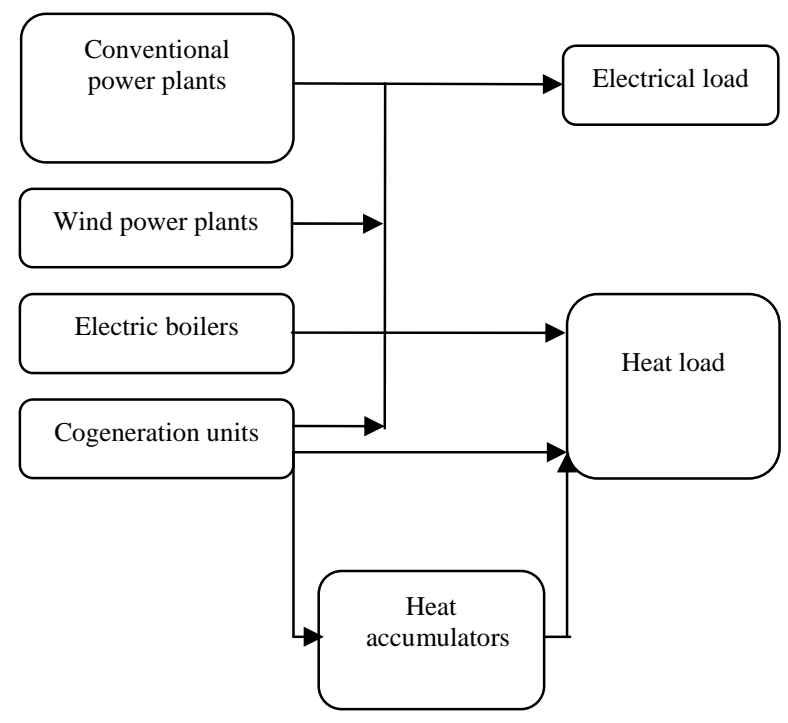

FIGURE I. DIAGRAM OF ACCOMMODATING WIND POWER CURTAILMENT BY COMBINED HEAT AND POWER PLANT

The project can improve regulating capacity of CHP units. The principle of accommodating wind power curtailment is showed in Figure I. When wind power is large and wind power curtailment appear, on the one hand electric boilers that installed in combined heat and power plant supply heat by consuming a part of wind power curtailment and electric power of CHP units are reduced by reducing heating power of CHP units, on the other hand electric power of CHP units are reduced by supplying heat of heat accumulators[10]. The on-grid spaces of wind power are increased to accommodating wind power curtailment by reducing electric power and lack of supply heat are compensated by electric boilers and heat accumulators. Accommodating curtailed wind power effectively is achieved with ensuring heating level.

\section{ECONOMIC BENEFITS OF AdVANCING Wind POWER ACCOMMODATION BASED ON ELECTRIC BOILER AND HEAT ACCUMULATOR}

\section{A. Costs Analysis of the Project}

The costs consist of initial construction costs, operating and maintenance costs and depreciations of electric boilers and heat accumulators. Initial construction costs consist of original equipment cost, construction cost and installation cost etc and are calculated refer to existing projects. Operating and maintenance costs consist of energy cost, operating personnel cost and quick-wear parts cost etc and are calculated by a certain proportion according to initial construction costs. Depreciations are calculated by a certain proportion according to initial construction costs.

Supposing capacity of electric boilers is $C_{E B}$, capacity of heat accumulators is $C_{H A}$, construction cost per unit of electric boilers is $u_{E B}$, construction cost per unit of heat accumulators is $u_{H A}$, service life of electric boilers and heat accumulators are both $N$. In consideration of using curtailed wind power to supply heat for electric boilers, short-term cost of electric boilers is 0 . Operating and maintenance costs of electric boilers and heat accumulators are respectively calculated by a certain proportion $\alpha$ and $\beta$. Depreciations are same per year and calculated by a certain proportion $\varepsilon$. The total costs $C$ per year of electric boilers and heat accumulators is:

$$
\begin{aligned}
& C=C_{E B} u_{E B} / N+C_{E B} u_{E B} \cdot \alpha+C_{E B} u_{E B} \cdot \varepsilon \\
& +C_{H A} u_{H A} / N+C_{H A} u_{H A} \cdot \beta+C_{H A} u_{H A} \cdot \varepsilon
\end{aligned}
$$

\section{B. Benefits Analysis of the Project}

According to the principle, benefit sources of accommodating curtailed wind power by electric boilers and heat accumulators include three parts: The first part is coal saving benefits of reducing consumption of coal by decreasing electric power of CHP units because of electric boilers supplying a part of heat instead of CHP units. The second part is coal saving benefits of reducing coal consumption by decreasing electric power of CHP units because of heat accumulators supplying a part of heat instead of CHP units. The third part is having a share in benefits of on-grid wind power owing to improving level of curtailed wind power by electric boilers and heat accumulators.

The first part benefit: saving consumption of coal per year $S_{E B}{ }^{[9]}$ by configuring electric boilers in combined heat and power plant:

$$
S_{E B}=0.1228 \frac{C_{E B} \beta_{E B}\left(1+\gamma_{C H P}\right)}{\beta_{C H P} \gamma_{C H P}} h_{E B}
$$

where $\beta_{E B}$ is heat production efficiency of electric boilers, $\beta_{C H P}$ is fuel efficiency of CHP units, $\gamma_{C H P}$ is heat-to-electric ratio of CHP units, $h_{E B}$ is average operation hours per year of electric boilers.

If the price of standard coal equivalent is $v$, coal saving benefits of electric boilers in combined heat and power plant:

$$
B_{E B}=0.1228 \frac{C_{E B} \beta_{E B}\left(1+\gamma_{C H P}\right)}{\beta_{C H P} \gamma_{C H P}} h_{E B} \nu
$$

The second part benefit: when curtailed wind power that are accommodated by CHP is $W_{W}$, saving consumption of coal ${ }^{[3]}$ is:

$$
S_{H A}=0.1228 \frac{\beta_{E B}\left(1+\gamma_{C H P}\right)}{\beta_{C H P}\left(\beta_{E B}+\gamma_{C H P}\right)} W_{W}
$$


In view of increasing accommodation of curtailed wind power by supplying heat of heat accumulators similar to electric boilers, saving consumption of coal by heat accumulators increasing accommodation of curtailed wind power is calculated by formula (4). Coal saving benefits of heat accumulators per year:

$$
B_{H A}=0.1228 \frac{\beta_{E B}\left(1+\gamma_{C H P}\right)}{\beta_{C H P}\left(\beta_{E B}+\gamma_{C H P}\right)} W_{W} v
$$

The third part benefit: when combined heat and power plant accommodates curtailed wind power by electric boilers and heat accumulators, it can not only invest in constructing electric boilers and heat accumulators but also lose profits due to reduce on-grid energy. Therefore combined heat and power plant will not adopt the scheme. Combined heat and power plant will actively take part in accommodating curtailed wind power if combined heat and power plant can share on-grid benefits of curtailed wind power.

Supposing feed-in tariff of wind power is $P_{W}$, generation cost per unit of wind power is $C_{W}$, share ratio of on-grid benefits of curtailed wind power is $\mu$, on-grid benefits of curtailed wind power of combined heat and power plant sharing is:

$$
B_{E H}=\mu W_{W}\left(P_{W}-C_{W}\right)
$$

The total benefits $B$ per year of electric boilers and heat accumulators is

$$
B=B_{E B}+B_{H A}+B_{E H}
$$

\section{Example Analysis}

A 300MW extraction condensation unit is as research subject in North China in the paper. Capacity of electric boilers is 10MW. Construction cost per unit of electric boilers is 1 million Yuan/MW. Capacity of heat accumulators is 20MW. Construction cost per unit of heat accumulators is 03 million Yuan/MW. Operating and maintenance costs ratio of electric boilers and heat accumulators are respectively $5 \%$ and $7 \%$. Service life are both 20 years. Heat production efficiency of electric boilers is 99\%. Fuel efficiency of CHP units is 0.7 because of operating under backpressure condition or minimum condensing condition for CHP during curtailed wind. Heat-to-electric ratio of CHP is 1 and 2 respectively. Depreciations ratio is 5\%. Average operation hours per year of electric boilers is $300 \mathrm{~h}$ and $400 \mathrm{~h}$ respectively. Coal price is 500 Yuan/t and amount to 715 Yuan/t of the price of standard coal equivalent. Feed-in tariff of wind power is $0.52 \mathrm{Yuan} / \mathrm{kWh}$ and generation cost per unit of wind power is $0.45 \mathrm{Yuan} / \mathrm{kWh}$.

\begin{tabular}{|c|c|c|c|c|c|}
\hline \multirow[b]{2}{*}{ Projects } & \multicolumn{5}{|c|}{ Projects } \\
\hline & $\begin{array}{l}\text { Equip } \\
\text { ments }\end{array}$ & Itens & $\begin{array}{l}h_{E B}=300 h \\
\gamma_{C H P}=2\end{array}$ & $\begin{array}{l}h_{E B}=400 h \\
\gamma_{C H P}=2\end{array}$ & $\begin{array}{l}h_{E B}=300 h \\
\gamma_{C H P}=1\end{array}$ \\
\hline \multirow{7}{*}{$\begin{array}{l}\text { The } \\
\text { total } \\
\text { costs } \\
C \\
\text { per } \\
\text { year }\end{array}$} & \multirow{3}{*}{$\begin{array}{l}\text { Electri } \\
\text { c } \\
\text { boilers }\end{array}$} & $\begin{array}{c}\text { Initial } \\
\text { constructio } \\
n \\
\text { costs(Yuan) } \\
\end{array}$ & 500000 & 500000 & 500000 \\
\hline & & $\begin{array}{c}\text { Operating } \\
\text { and } \\
\text { maintenanc } \\
\text { e } \\
\text { costs(Yuan) }\end{array}$ & 500000 & 500000 & 500000 \\
\hline & & $\begin{array}{c}\text { Depreciatio } \\
\text { ns(Yuan) }\end{array}$ & 500000 & 500000 & 500000 \\
\hline & \multirow{3}{*}{$\begin{array}{l}\text { Heat } \\
\text { accum } \\
\text { ulators }\end{array}$} & $\begin{array}{c}\text { Initial } \\
\text { constructio } \\
n \\
\text { costs(Yuan) } \\
\end{array}$ & 300000 & 300000 & 300000 \\
\hline & & $\begin{array}{c}\text { Operating } \\
\text { and } \\
\text { maintenanc } \\
\text { e } \\
\text { costs(Yuan) }\end{array}$ & 420000 & 420000 & 420000 \\
\hline & & $\begin{array}{c}\text { Depreciatio } \\
\text { ns(Yuan) }\end{array}$ & 300000 & 300000 & 300000 \\
\hline & \multicolumn{2}{|c|}{ Totals(Yuan) } & $\begin{array}{c}252000 \\
0 \\
\end{array}$ & $\begin{array}{c}252000 \\
0 \\
\end{array}$ & $\begin{array}{c}252000 \\
0 \\
\end{array}$ \\
\hline \multirow{10}{*}{$\begin{array}{c}\text { The } \\
\text { total } \\
\text { benefits } \\
B \\
\text { per } \\
\text { year }\end{array}$} & \multirow{4}{*}{$\begin{array}{l}\text { Electri } \\
\text { c } \\
\text { boilers }\end{array}$} & $\begin{array}{c}\text { Curtailed } \\
\text { wind power } \\
\text { Consumpti } \\
\text { on (MWh) }\end{array}$ & 3000 & 4000 & 3000 \\
\hline & & $\begin{array}{c}\text { Power } \\
\text { reduction } \\
(\mathrm{MWh})\end{array}$ & 1485 & 1980 & 2970 \\
\hline & & $\begin{array}{l}\text { Coal saving } \\
\text { (t) }\end{array}$ & 782 & 1042 & 1042 \\
\hline & & $\begin{array}{l}\text { Benefits of } \\
\text { coal } \\
\text { saving(Yua } \\
\text { n) } \\
\end{array}$ & 560000 & 745000 & 745000 \\
\hline & \multirow{3}{*}{$\begin{array}{l}\text { Heat } \\
\text { accum } \\
\text { ulators }\end{array}$} & $\begin{array}{c}\text { Curtailed } \\
\text { wind power } \\
\text { accommoda } \\
\text { tion (MWh) }\end{array}$ & 13500 & 13500 & 13500 \\
\hline & & $\begin{array}{l}\text { Coal saving } \\
\text { (t) }\end{array}$ & 2352 & 2352 & 2352 \\
\hline & & $\begin{array}{c}\text { Benefits of } \\
\text { coal } \\
\text { saving(Yua } \\
\mathrm{n}) \\
\end{array}$ & $\begin{array}{c}168000 \\
0\end{array}$ & $\begin{array}{c}168000 \\
0\end{array}$ & $\begin{array}{c}168000 \\
0\end{array}$ \\
\hline & \multirow{2}{*}{$\begin{array}{l}\text { Electri } \\
\text { c } \\
\text { boilers } \\
\text { \& } \\
\text { Heat } \\
\text { accum } \\
\text { ulators }\end{array}$} & $\begin{array}{l}\text { Increasing } \\
\text { curtailed } \\
\text { wind power } \\
\text { accommoda } \\
\text { tion (MWh) }\end{array}$ & 14985 & 15480 & 16470 \\
\hline & & $\begin{array}{c}\text { Benefits } \\
\text { sharing(Yu } \\
\text { an) }\end{array}$ & 525000 & 542000 & 576000 \\
\hline & \multicolumn{2}{|c|}{ Totals(Yuan) } & $\begin{array}{c}276500 \\
0 \\
\end{array}$ & $\begin{array}{c}296700 \\
0 \\
\end{array}$ & $\begin{array}{c}300100 \\
0 \\
\end{array}$ \\
\hline \multicolumn{3}{|c|}{ Comprehensive profits(Yuan) } & 245000 & 447000 & 481000 \\
\hline
\end{tabular}
Share ratio of on-grid profits of curtailed wind power is $50 \%$.
TABLE I. ANALYSIS OF COSTS AND BENEFITS

The total costs $C$ per year, the total benefits $B$ per year and comprehensive profits of the method are showed in Tab.1. According to Tab.1, if other conditions are not changed and average operation hours per year of electric boilers $h_{E B}$ is changed from $300 \mathrm{~h}$ to $400 \mathrm{~h}$, comprehensive profits increase by 1.82. If other conditions are not changed and heat-to-electric 
ratio of CHP units $\gamma_{C H P}$ is changed from 2 to 1 , comprehensive profits increase by 1.96 .

\section{CONCLUSION}

Aim at the problem of tremendous wind power curtailment in the north power grid of China, the method of decoupling the constraint of forced power output determined by heat by configuring large electric boiler and heat accumulator for CHP is proposed. By Economic benefits analysis of the project, there are significant benefits of coal saving by using wind power to supply power and heat instead of CHP units. Since some factors such as average operation hours per year of electric boilers $h_{E B}$ and heat-to-electric ratio of CHP units $\gamma_{C H P}$ dramatically influence economic benefits of the project, the project has priority to be applied to the conditions of large curtailed wind power, long curtailed wind time and small heat-to-electric ratio of CHP units.

\section{ACKNOWLEDGMENT}

The research was supported by "the Fundamental Research Funds for the Central Universities of China" (Grant No.13MS81).

\section{REFERENCES}

[1] State Electricity Regulatory Commission. Supervision report on wind power accommodation in key areas (No.10, 2012)[R]. Beijing: State Electricity Regulatory Commission, 2012.

[2] Yan Gangui, Liu Jia, Cui Yang, Mu Gang, Li Junhui,Xu Guangxin. Economic evaluation on improving wind power scheduling scale by using energy storage systems[J]. Proceedings of the CSEE, 2013, 33(22): 45-52.

[3] Zheng Le, Hu Wei, Lu Qiuyu, Min Yong, Yuan Fei, Gao Zonghe. Research on planning and operation model for energy storage system to optimize wind power integration[J]. Proceedings of the CSEE, 2014, 34(16): 2533-2543.

[4] Xu Fei, Min Yong, Chen Lei, Chen Qun, Hu Wei, Zhang Weiling, Wang Xiaohai, Hou Youhua. Combined electricity-heat operation system containing large capacity thermal energy storage[J]. Proceedings of the CSEE, 2014, 34(29): 5063-5072.

[5] Yuan Xiaoming, Cheng Shijie, Wen Jinyu. Prospects analysis of energy storage application in grid integration of large-scale wind power[J]. Automation of Electric Power Systems, 2013, 37(1): 14-18.

[6] CHRISTIDIS A, KOCH C, POTTEL L, et al. The contribution of heat storage to the profitable operation of combined heat and power plants in liberalized electricity markets[J]. Energy, 2012, 41(1): 75-82.

[7] LUND H, ANDERSEN A N. Optimal designs of small CHP plants in a market withfluctuating electeicity prices[J]. Energy Conversion and Management, 2005, 46(6):893-904.

[8] Li Qunying, Feng Limin, Xu Yuhui, Li Chunliang, Wang Shaoran. Accommodation mode of wind power based on water source heat pump technology[J]. Automation of Electric Power Systems, 2012, 36(17): 25-27.

[9] Lü Quan, Jiang Hao, Chen Tianyou, Wang Haixia, Lü Yang, Li Weidong. Wind power accommodation by combined heat and power plant with electric boiler and its national economic evaluation[J]. Automation of Electric Power Systems, 2014, 38(1): 6-12.

[10] Lü Quan, Chen Tianyou, Wang Haixia, Yu Ting, Li Qun, Tang Wei. Analysis on peak-load regulation ability of CHP with heat accumulator[J]. Automation of Electric Power Systems, 2014, 38(11): $34-41$ 